\title{
$\mathrm{DQ}$ 와 단기 상대생장률 분석을 이용한 원통형 종이포트 토마토 접목묘의 우량묘 기준 설정
}

\author{
서태철 ${ }^{1,3 *} \cdot$ 안세웅 $^{1} \cdot$ 장현우 $^{1} \cdot$ 남춘우 $^{1} \cdot$ 전희 $^{1} \cdot$ 김영철 ${ }^{1} \cdot$ 강태경 $^{2} \cdot$ 이상희 $^{2}$ \\ 1국립원예특작과학원 채소과, ${ }^{2}$ 국립농업과학원 밭농업기계화팀, ${ }^{3}$ 세계채소센터
}

\section{An Approach to Determine the Good Seedling Quality of Grafted Tomatoes (Solanum Lycopersicum) Grown in Cylindrical Paper Pot Through the Relation Analysis between DQI and Short-Term Relative Growth Rate}

\author{
Tae Cheol Seo ${ }^{1,3 *}$, Se Woong An ${ }^{1}$, Hyun Woo Jang ${ }^{1}$, Chun Woo Nam ${ }^{1}$, Hee Chun ${ }^{1}$, \\ Young chul Kim ${ }^{1}$, Tae Kyung Kang ${ }^{2}$, and Sang Hee Lee ${ }^{2}$ \\ ${ }^{1}$ Vegetable Research Division, National Institute of Horticultural and Herbal Science, RDA, Wanju, 55365, Korea \\ ${ }^{2}$ Upland Mechanization Team, National Institute of Agricultural Sciences, RDA, Jeonju, 54875, Korea \\ ${ }^{3}$ World Vegetable Center, Shanhua, 74199, Taiwan
}

\begin{abstract}
Using cylindrical paper pot nursery method, three kinds of commercial tomatoes 'Dafnis', 'DOTAERANG DIA' and 'Maescala' were grafted onto a commercial rootstock 'B blocking'. From 10 to 40 days after graft-take, growth traits of seedlings were investigated by $0.5,1.0$ and $2.0 \mathrm{~S}$ treatments of standard nutrient solution(S) for seedling growth, and top to root ratio(TRR), compactness(CP) and Dickson Quality Index(DQI) were calculated. Two weeks after transplanting of the seedlings under three different night temperature targeting to 10,15 , and $25^{\circ} \mathrm{C}$, which were not precisely controlled, the relative growth rate (RGR) was investigated. The quantitative growth traits of grafted seedlings increased with increasing fertilizer concentration, and various range of seedling size could be produced. Compactness and DQI were significantly regressed (Adj $\mathrm{R}^{2}=0.9480$ ). Short-term RGR after transplanting was higher at $1.0 \mathrm{~S}$ treatment of standard nutrient solution at the seedling age of 30 days and 40 days after grafttake(DAGT). DQI and RGR were significantly regressed linearly at respective fertigation strength. Specially the diminishing slope of RGR was lower at 1.0S fertigation strength with the increase of DQI than others. The results indicate that DQI could be applied as a quality index of grafted tomato seedlings and the relation analysis between DQI and short-term RGR also could be used to determine the good quality seedlings of grafted tomato grown in cylindrical paper pot.
\end{abstract}

Additional key words : raising seedling, determination, criteria, performance, absolute growth rate

\section{서 론}

원통형 종이포트 육묘시스템은 유럽이나 미국에서 수 목이나 화훼류의 육묘에 사용되는 방법으로 국내에서도 2014년에 강원도 춘천의 한 육묘장에서 채소묘 생산을 위하여 처음으로 도입되었고, 최근까지 약 10 여 개소 이 상에서 채소묘 생산에 활용되고 있다(Seo et al., 2017). 원통형 종이포트 묘는 모종을 뽑기가 쉽고, 어린 묘를 옮겨 심어도 근권부가 부서짐이 거의 없어 정식 후 활

*Corresponding author: tcseo2@korea.kr

Received July 13, 2018; Revised September 11, 2018;

Accepted October 1, 2018
착이 용이하다(Ellepot, 2017). 또한, 원통형 종이포트 묘 는 기본적으로 프러그 트레이에 종이포트를 넣고 육묘하 기 때문에 외양적으로는 프러그묘와 비슷하여 육묘농가 와 생산농가들에겐 거부감이 없을 것으로 생각되지만 물 리적인 환경이 다소 다르므로 앞으로 기술 보급을 위한 많은 검토가 필요하다.

묘소질은 육묘 과정에서 묘가 지니고 있는 성질 또는 능력으로서, 우량묘는 생산의 안정과 효율을 높일 수 있 는 모종으로 일반적으로 강건한 모종, 동화능력이 큰 모 종, 과채류는 소질이 좋은 꽃눈이 많은 모종(RDA, 2008)으로 알려져 있다. 따라서 많은 연구자들은 묘소질 과 관련된 연구를 수행하였다(Leskovar and Stoffella, 1995; Mattson, 1996; Ahn et al., 2003; Seo et al., 
2006; Lee et al., 2012; Kim et al., 2013; Kim et al., 2015). 묘소질에 대한 연구의 가장 기본적인 출발은 묘 소질의 기준, 즉 어떤 생육인자가 묘소질에 가장 결정적 인 역할을 하는 것인가이다. 현재까지 알려진 묘소질의 지표로는 Dickson quality index (DQI) (Dickson et al., 1960), T/R율(Kubo et al., 1991), 충실도(박 등, 1996) 등 이 있다. DQI는 산림 묘목에 대한 묘소질 지표로 개발되 었고 최근에도 활용되고 있다(Mota 등, 2016). 한편, 묘소 질이 정식 후에 식물체의 능력발휘에 미치는 직접적인 관 계를 밝히는 것은 다양한 환경요인과 재배기술 요인 등이 복합적으로 관여되어 있으므로 그 구명이 용이하지 않다. 상대생장률(RGR)의 조사는 식물 모형 연구자들이 주로 이용하는 항목으로 식물종과 생육단계에 의존하여 변하는 식물의 크기에 값이 달라지는 단점에도 불구하고 많은 연 구에 활용되고 있다(Shipley, 2006; Rees et al., 2010).

본 연구는 최근에 도입된 원통형 종이포트 육묘기술을 적용하여, 육묘기에 시비 수준 처리에 따른 토마토 접목 묘의 묘령별 생육인자와 묘소질과의 관계분석과 정식 후 야간온도 처리에 다른 단기 상대생장률 분석을 통해서 우량묘의 기준설정 가능성을 검토하고자 수행되었다.

\section{재료 및 방법}

\section{1. 재배 조건 및 식물 재료}

본 실험은 전라북도 전주의 국립원예특작과학원 채소 과 온실의 육묘온실에서 2017년 3월 10일부터 6월 1일 까지 수행되었다. 육묘온실은 남북동으로 길이 $38 \mathrm{~m}$, 폭 $24 \mathrm{~m}$, 측고 $4.5 \mathrm{~m}$ 벤로형 유리온실로 가운데 $3 \mathrm{~m}$ 복도가 있으며, 양쪽으로 3 개의 육묘용 공간이 있는 구조이며, 온도조절은 천창과 측장, 그리고 강제환기팬을 이용하여 Priva 시스템(Priva PV., 네덜란드)으로 자동으로 이루어
졌다. 육묘기간 중의 평균 온도, 최고온도, 최저온도는 $23.1 \pm 2.7^{\circ} \mathrm{C}, 33.4 \pm 4.2^{\circ} \mathrm{C}, 17.2 \pm 2.5^{\circ} \mathrm{C}$ 로 측정되었다.

일반 토마토 품종 ‘대프니스(신젠타코리아)', ‘도테랑다 이아(한국다끼이)', '마스카라(부종종묘)'는 접수, ' $\mathrm{B}$ 블로 킹(한국다끼이)'은 대목으로 사용하였다. 2017년 3월 10 일에 접수는 '흥농바이오1호(흥농종묘사, 한국)' 상토를 채운 105 공 플러그트레이, 대목은 피트모스 주재료인 상 토를(Pindstrup, 덴마크) 충전한 원통형 종이포트(부피 $53 \mathrm{~mL}$ ) 40 구 트레이(범농, 한국)에 각각 파종하였다. 온 도 $28^{\circ} \mathrm{C}$, 습도 $90 \%$ 의 발아실에서 2 일 동안 경과 후 육 묘온실에서 1 차 육묘하였다. 1 차 육묘 기간 중에는 안정 적인 발아를 위해 저면관수 방법으로 관수하였다. 접목 은 4월 5 일에 본엽 1 엽 위치에서 편엽합접 방법으로 하 였으며, 접목 후 LED 등이 부착된 대차에 올려놓고 온 도 $26^{\circ} \mathrm{C}$, 습도 $90 \%$ 조건의 활착실에서 5 일간 활착시킨 후 4월 9일부터 육묘온실에서 2차 육묘하였다.

\section{2. 육묘기 시비 처리}

육묘기 시비용 양액은 원예연 개발 육묘용양액(EC $1.5 \pm 0.1 \mathrm{dS} \cdot \mathrm{m}^{-1}$, N-P-K-Ca-Mg-S = 8.0-2.4-2.4-4.8-1.6-1.6 $\left.\mathrm{me} \cdot \mathrm{L}^{-1}\right)$ 을 사용하였고, 시비처리는 육묘용 양액 표준농도 $(\mathrm{S})$ 의 $0.5 \mathrm{~S}, 1.0 \mathrm{~S}, 2.0 \mathrm{~S}$ 3수준으로 접목활착 후부터 일주 일에 2 회 처리 하였다. 시비방법은 접목활착 후 일주일 까지는 저면급액방법으로 하였으며, 그 이후부터는 두상 시비하였다. 시비처리 기간중 관수는 시들지 않도록 매 일 1 2차례 두상관수 하였다.

\section{3. 정식 후 야간온도 처리}

이식 후 2주 동안의 상대생장률(Relative growth rate, $\mathrm{RGR}$ )을 조사하기 위해 육묘기 시비처리를 받은 접목활착 후 10 일, 20 일, 30 일 40 일 간 자란 묘를 각각 4월 19일, 4

Table 1. Mean, maximum, and minimum temperature during night temperature treatment inside the glass house.

\begin{tabular}{cccccc}
\hline \hline Night temperature Treatments $\left({ }^{\circ} \mathrm{C}\right)$ & 10 DAGT & 20 DAGT & 30 DAGT & 40 DAGT \\
\hline \multirow{2}{*}{10} & Mean & $23.7 \pm 2.0$ & $24.8 \pm 1.5$ & $25.0 \pm 1.7$ & $27.2 \pm 1.4$ \\
& Max & $36.0 \pm 3.8$ & $36.8 \pm 3.8$ & $35.9 \pm 3.6$ & $38.7 \pm 2.2$ \\
& Min & $15.8 \pm 1.7$ & $17.9 \pm 1.4$ & $18.0 \pm 1.4$ & $19.3 \pm 1.7$ \\
\multirow{2}{*}{15} & Mean & $24.2 \pm 1.9$ & $25.5 \pm 1.3$ & $25.9 \pm 1.7$ & $27.9 \pm 1.4$ \\
& Max & $33.7 \pm 3.4$ & $35.0 \pm 3.2$ & $36.4 \pm 4.6$ & $40.4 \pm 2.9$ \\
& Min & $17.9 \pm 1.7$ & $20.0 \pm 1.1$ & $19.9 \pm 1.4$ & $20.7 \pm 1.4$ \\
& Mean & - & - & $28.0 \pm 1.7$ & $29.1 \pm 1.1$ \\
& Max & - & - & $36.1 \pm 4.1$ & $39.8 \pm 2.1$ \\
& Min & - & - & $23.7 \pm 1.7$ & $24.0 \pm 0.8$ \\
\hline
\end{tabular}

${ }^{\mathrm{z}}$ Day after graft-taking.

${ }^{\mathrm{y}}$ Missing data. 
월 29일, 5월 8일, 5월 18일에 시판상토 '흥농바이오1호' 를 채운 $\Phi 15 \mathrm{~cm}$ 플라스틱 포트에 옮겨 심은 후에 폿트에 크기에 맞는 6 구 연결 트레이에 담아서 배치한 후 야간온 도 처리를 하였다. 야간온도 처리는 $10^{\circ} \mathrm{C}, 15^{\circ} \mathrm{C}, 25^{\circ} \mathrm{C}$ 의 3 수준을 목표로 처리하였다. 야간온도 처리를 위해 유리온
실 안에 하우스용 파이프로 만든 터널 프레임을 벤치위에 설치하고 $\mathrm{PE}$ 필름으로 덮었다(Fig. 1). 야간에 열을 공급 하기 위해 벤치 아래에 소형 전기 히터 (P-1800F, 무창상 사, 중국)를 설치 후 온도조절기와 연결하여 야간온도를 조절하였다. 주간에는 측면 필름을 걷어 올려서 온실내 공
A

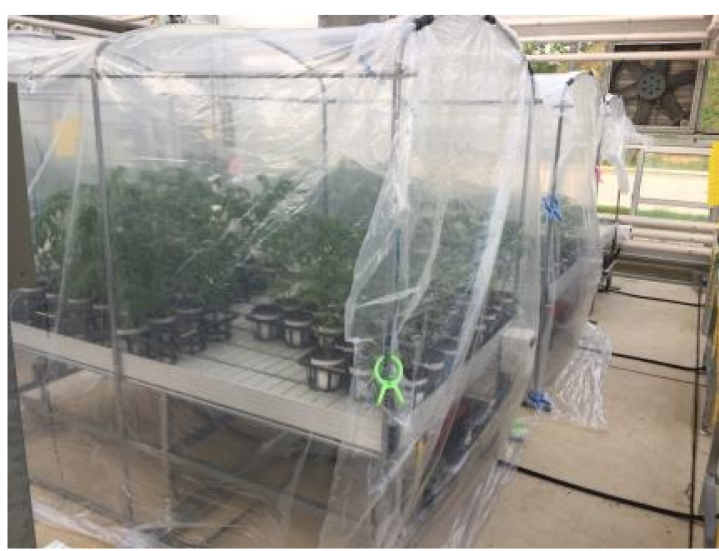

C

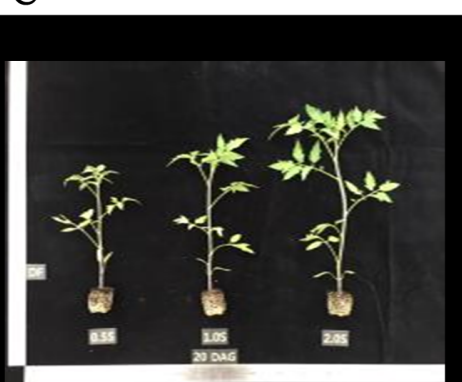

D

\section{B}

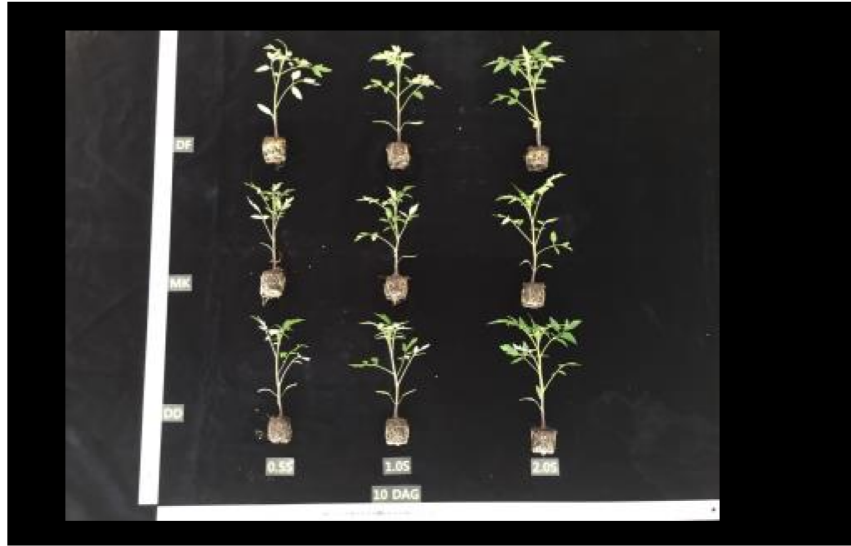

$\mathrm{E}$
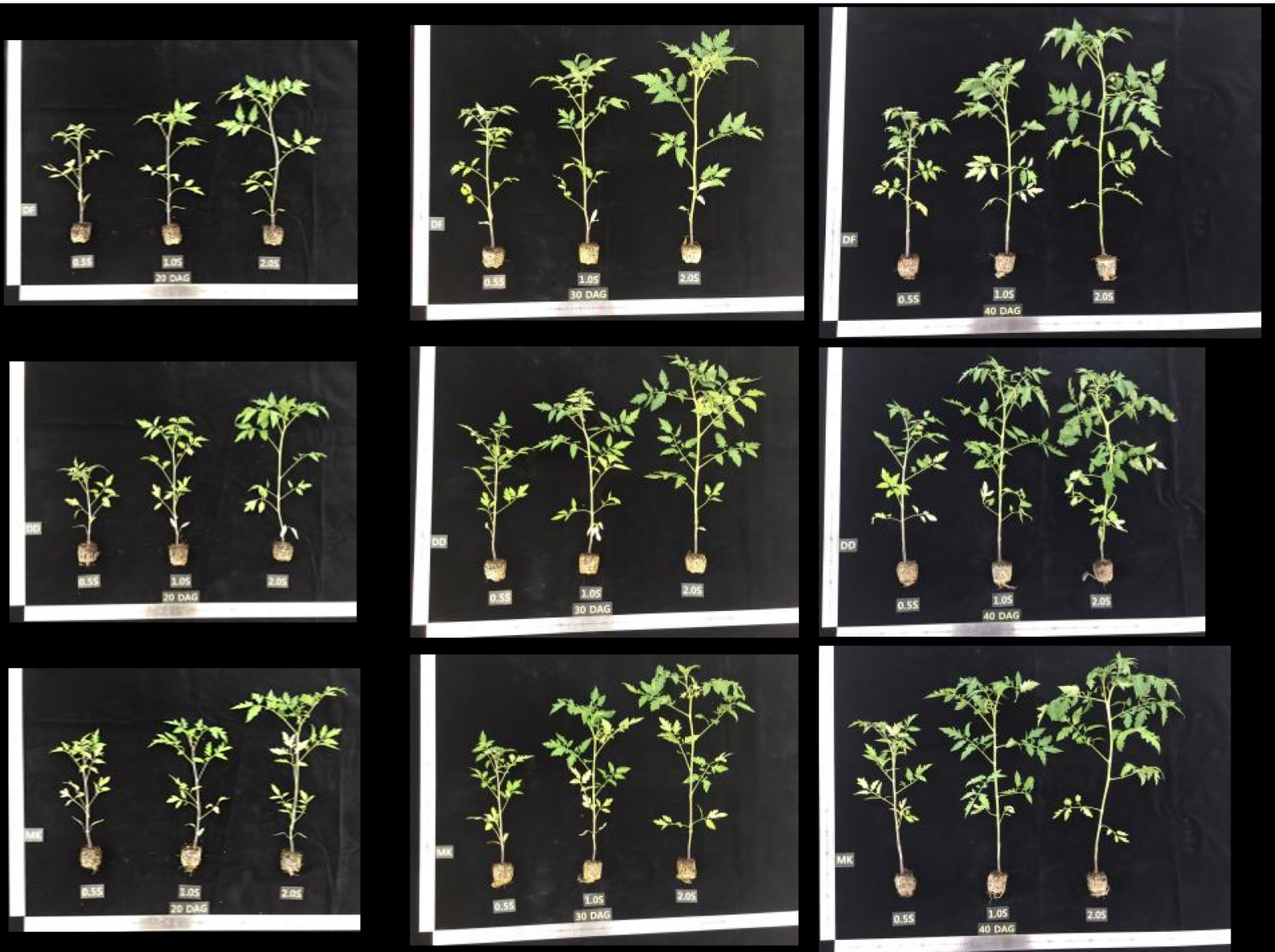

Fig. 1. Photo of small tunnel for night temperature in the nursery glass house (A), and the seedling growth of three kinds of tomatoes at 10 DAGT (B), 20 DAGT (C), 30 DAGT (D), and 40 DAGT (E) as affected by the strength of nutrient solution for fertigation. 
기 유통이 되도록 하였다. 그러나 실제 온도는 처리설정 온도보다 높게 유지되었는데, 이것은 5 월 이후 야간온도 $10^{\circ} \mathrm{C}$ 이상의 외기온과 $15^{\circ} \mathrm{C}$ 와 $25^{\circ} \mathrm{C}$ 의 야간 온도 처리에 따른 온도 상승 등이 작용한 것으로 판단되었다(Table 1).

\section{4. 묘소질 및 상대생장률 조사}

묘소질 조사는 각 시기 마다 품종별로 각 트레이별로 3주씩 채취하였으며(Fig. 1), 3반복으로 조사하였다. 조사 항목으로는 초장, 경경, 엽수, 엽색, 엽면적, 생체중과 건 물중을 조사하였다. 조사방법은 다음과 같다. 초장은 줄 자로 지제부에서 선단부까지 길이, 경경은 디지털 켈리 퍼스로 접목부위 위 $1 \mathrm{~cm}$ 부위의 직경, 엽수는 소엽폭 기준 $1 \mathrm{~cm}$ 이상의 본엽 수, 엽색은 휴대용 엽록소계 (SPAD-502, KONICA MINOLTA, 일본)로 가장 크게 전개된 잎을 3 회 측정하여 평균값을 산출하였다. 엽면적 은 엽면적계(LI-3100C, LI-COR, 미국)로 측정하였다. 생 체중은 식물체 뿌리를 지하수로 세척한 후에 잎, 줄기, 뿌리로 나누어 전자저울로 부위별로 측정하였고, 건물중 은 공기순환 건조기에서 $75^{\circ} \mathrm{C}$ 조건에서 완전히 건조한 후에 측정하였다. 이 후 $\mathrm{TR}$ 율[지상부건물중 $(\mathrm{g}) /$ 지하부건 물중 $(\mathrm{g})$ 과 충실도[지상부건물중 $(\mathrm{mg})$ 초장 $(\mathrm{cm})]$, 그리고 Dickson Quality Index (DQI)는 다음과 같은 식으로 계 산하였다(Dickson et al., 1960).

$$
\mathrm{DQI}=\mathrm{TDW} /(\mathrm{PH} / \mathrm{SD}+\mathrm{SDW} / \mathrm{RDW})
$$

$[\mathrm{PDW}$; 식물체건물중 $(\mathrm{g}), \mathrm{PH}$; 초장 $(\mathrm{cm}), \mathrm{SD}$; 경경 $(\mathrm{mm}), \mathrm{SDW}$; 지상부건물중 $(\mathrm{g}), \mathrm{RDW}(\mathrm{g})]$

상대생장률(RGR)의 조사는 각 묘령별로 2 주간의 야간온 도 처리 후 1 포트를 반복으로 3 반복으로 생육조사를 실시 하고 Hoffmann과 Pooter(2002)의 방법에 따라 계산하였다.

$$
\mathrm{RGR}=\operatorname{Ln}\left(\mathrm{W}_{2}\right)-\operatorname{Ln}\left(\mathrm{W}_{1}\right) / \mathrm{t}_{2}-\mathrm{t}_{1}
$$

[RGR; 상대생장률 $\left(\mathrm{g} \cdot \mathrm{g}^{-1} \cdot \mathrm{d}^{-1}\right), \mathrm{W}_{2}$ : 정식 2 주 후 식물체 건물중 $(\mathrm{g}), \mathrm{W}_{1}$ : 정식 시 식물체건물중 $\left.(\mathrm{g})\right]$

\section{5. 실험구 배치 및 통계분석}

실험구 배치는 완전임의배치 3 반복으로 배치하였으며, 통계분석은 SAS 통계 소프트웨어 9.3과 SAS Studio (SAS Institute, Cary, USA), 그리고 SigmaPlot 10.0 (Systat Software, Inc, USA)를 이용하여 분석하였다. 분 석방법은 각 처리 요인별로 분산분석과 $\mathrm{F}$ 검정을 통하여 처리효과를 분석하였으며, 묘의 생육인자와 묘소질 지표 와의 상관분석, 그리고 묘소질 지표간 및 묘소질지표와 상대생장률과의 회귀분석을 하였다.

\section{결과 및 고찰}

원통형 종이포트를 이용한 토마토 접목묘는 육묘기간 이 경과함에 따라 생육량은 증가하였다(Fig. 1). 또한 시 비수준 처리가 어느 정도 접목 토마토묘 생육의 양적인 변화를 가져오는 지를 알아보기 위해 묘령별로 생육인자 들의 양적인 변이 범위를 종합한 결과, 시비수준 처리에 따른 생육인자들의 변이계수는 접목 활착 후 생육일수가 경과할수록 높아졌으며, 생육인자별로는 엽면적, 생체중, 건물중, 초장, 경경 및 엽색 순으로 높았다(Table 2). 이 러한 결과는 시비수준에 따라 묘의 생육이 상당히 큰 영향을 받으며, 다양한 크기의 묘의 형태로 나타남을 확 인할 수 있었다(Lee et al., 2001; Ballieu et al., 2007).

그리고 실험기간 동안 원통형 종이포트에서 자란 토마 토 접목묘의 각각의 생육인자들과 묘소질을 나타내는 $\mathrm{TR}$ 율, 충실도(compactness), 그리고 $\mathrm{DQI}$ 와의 상관관계를 분석한 결과, 충실도와 $\mathrm{DQI}$ 는 모든 생육인자들과 정의 상관이 있었고 특히, 식물체 무게를 나타내는 지표와 높 은 정의상관이 있었다. 그러나 TR율은 경경, 엽색, 뿌리 중량과는 상관이 없는 것으로 나타났으며, 정의 상관을 보인 생육지표의 경우에도 낮은 정의상관을 보였다 (Table 3). 묘소질 지표를 나타내는 TR율, 충실도, 그리 고 $\mathrm{DQI}$ 를 시비수준 처리에 따른 처리효과를 각각 Table 4, 5 및 6에 나타내었다. TR율은 6.7 7.4 범위에서 유지 되었으며, 묘령이 증가함에 따른 의미 있는 변화는 없었 다(Table 4). 그러나 시비수준 처리에 따라서는 유의적인 차이를 보였는데, 특히 접목 활착 20 일 후 $2.0 \mathrm{~S}$ 처리에 서 높았다. 일반적으로 $\mathrm{TR}$ 율은 시비농도가 높아질수록

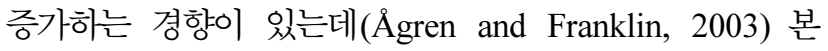
실험에서도 같은 결과를 나타내었다. 품종별로는 모든 묘령에서 '도태랑다이아' 품종이 다른 두 품종에 비해 높았는데, 'B블로킹'을 대목으로 사용했기 때문에, TR율 의 차이를 접수의 차이만으로 해석할 수는 없다고 판단 된다. 단지, 접목활착율은 유관상 모두 잘 이루어졌기 때문에 접목친화성의 차이는 아닌 것으로 생각되며 일본 계 완숙토마토 품종인 '도태랑다이아'가 나머지 두 유럽 계 토마토보다 시비농도에 더 민감하게 반응한 것이라고 보여진다.

충실도의 경우 묘령이 증가할수록 높아졌으며(Table $5)$, 접목활착 후 10 일과 20 일묘는 시비수준에 따른 차이 는 없었으나 접목활착 후 30 일에는 시비수준 $2.0 \mathrm{~S}$ 처리 가 $1.0 \mathrm{~S}$ 와 $0.5 \mathrm{~S}$ 보다 높았으며, 접목활착 후 40 일에는 차 이가 없어졌다. 품종별로는 접목활착 후 30 일에 '대프니 스'가 나머지 두 품종보다 높은 것으로 나타났다. 이 시 기에는 시비수준과 품종에 따른 상호작용 효과도 있었는 데, $1.0 \mathrm{~S}$ 농도에서는 품종별 차이가 없었으나 $0.5 \mathrm{~S}$ 와 
서태철 · 안세웅 · 장현우 · 남춘우 · 전희 · 김영철 · 강태경 · 이상희

Table 2. Overall range of grafted tomato seedling growth traits investigated at 10, 20, 30, 40 days after graft-take (DAGT) as affected by the strength of nutrient solution for fertigation.

\begin{tabular}{|c|c|c|c|c|c|c|c|c|c|}
\hline $\begin{array}{l}\text { DAGT } \\
\text { (Days) }\end{array}$ & Basic statistics & $\begin{array}{l}\mathrm{PH}^{\mathrm{z}} \\
(\mathrm{cm})\end{array}$ & $\begin{array}{l}\mathrm{SD}^{\mathrm{y}} \\
(\mathrm{mm})\end{array}$ & $\begin{array}{l}\mathrm{NL}^{\mathrm{x}} \\
\text { (ea) }\end{array}$ & $\begin{array}{c}\mathrm{LC}^{\mathrm{w}} \\
\text { (SPAD value) }\end{array}$ & $\begin{array}{l}\mathrm{LA}^{\mathrm{v}} \\
\left(\mathrm{cm}^{2}\right)\end{array}$ & $\begin{array}{c}\mathrm{FW}^{\mathrm{u}} \\
\text { (g/plant) }\end{array}$ & $\begin{array}{c}\mathrm{DW}^{\mathrm{t}} \\
\text { (g/plant) }\end{array}$ & $\begin{array}{c}\mathrm{T} / \mathrm{R}^{\mathrm{s}} \\
\left(\mathrm{g} \mathrm{g}^{-1}\right)\end{array}$ \\
\hline \multirow[t]{5}{*}{10} & Mean & 21.8 & 3.30 & 6.57 & 37.8 & 71.5 & 4.098 & 0.411 & 6.74 \\
\hline & $\mathrm{SD}^{\mathrm{r}}$ & 2.3 & 0.21 & 0.67 & 2.4 & 17.2 & 0.769 & 0.050 & 1.44 \\
\hline & $\operatorname{Max}^{\mathrm{q}}$ & 26.4 & 3.67 & 7.67 & 41.6 & 98.5 & 5.458 & 0.499 & 10.80 \\
\hline & $\operatorname{Min}^{p}$ & 17.9 & 2.92 & 5.33 & 29.9 & 46.7 & 2.959 & 0.319 & 4.42 \\
\hline & $\mathrm{CV}^{\mathrm{o}}$ & 10.4 & 6.4 & 10.2 & 6.3 & 24.1 & 18.8 & 12.1 & 21.4 \\
\hline \multirow[t]{5}{*}{20} & Mean & 32.6 & 3.47 & 8.84 & 38.1 & 143.2 & 8.729 & 1.087 & 7.40 \\
\hline & SD & 5.7 & 0.21 & 0.97 & 2.6 & 55.1 & 2.605 & 0.218 & 1.50 \\
\hline & Max & 45.5 & 3.93 & 10.67 & 43.3 & 233.4 & 13.233 & 1.426 & 9.96 \\
\hline & Min & 24.3 & 3.18 & 7.33 & 33.4 & 73.7 & 5.172 & 0.723 & 4.90 \\
\hline & $\mathrm{CV}$ & 17.6 & 6.0 & 11.0 & 6.9 & 38.5 & 29.8 & 20.1 & 20.3 \\
\hline \multirow[t]{5}{*}{30} & Mean & 40.4 & 3.77 & 10.43 & 41.5 & 218.9 & 14.457 & 1.967 & 6.58 \\
\hline & SD & 8.4 & 0.28 & 1.18 & 3.6 & 95.0 & 5.084 & 0.547 & 1.15 \\
\hline & Max & 54.7 & 4.27 & 12.67 & 48.6 & 393.4 & 23.104 & 2.899 & 8.54 \\
\hline & Min & 26.9 & 3.22 & 8.67 & 36.1 & 105.6 & 7.998 & 1.086 & 4.90 \\
\hline & $\mathrm{CV}$ & 20.8 & 7.4 & 11.3 & 8.8 & 43.4 & 35.2 & 27.8 & 17.5 \\
\hline \multirow[t]{5}{*}{40} & Mean & 49.4 & 3.97 & 11.48 & 42.9 & 318.8 & 20.799 & 3.085 & 7.02 \\
\hline & SD & 8.8 & 0.31 & 1.08 & 2.8 & 150.1 & 7.266 & 0.786 & 1.68 \\
\hline & Max & 65.0 & 4.64 & 13.33 & 47.2 & 570.4 & 32.357 & 4.360 & 10.36 \\
\hline & Min & 36.0 & 3.54 & 10.00 & 36.0 & 156.8 & 12.264 & 2.080 & 4.31 \\
\hline & $\mathrm{CV}$ & 17.8 & 7.7 & 9.4 & 6.5 & 47.1 & 34.9 & 25.5 & 23.9 \\
\hline
\end{tabular}

${ }^{\mathrm{z}}$ Plant height; ${ }^{\mathrm{y}}$ Stem diameter; ${ }^{\mathrm{x}}$ Number of leaf; ${ }^{\mathrm{w}}$ Leaf color; ${ }^{\mathrm{v}}$ Leaf area; ${ }^{\mathrm{u}}$ Fresh weight; ${ }^{\mathrm{t}}$ Dry weight; ${ }^{\mathrm{s}}$ Top to root ratio; ${ }^{\mathrm{r}}$ Standard deviation; ${ }^{\mathrm{q}}$ Maximum value; ${ }^{\mathrm{p}}$ Minimum value, ${ }^{\circ} \mathrm{Coefficient}$ of variation.

Table 3. Pearson linear correlation matrix of the growth traits and the seedling quality of grafted tomato seedlings grown in paper pot trays from 10 DAGT to 40 DAGT.

\begin{tabular}{cccccccccccccc}
\hline \hline & $\mathrm{PH}^{\mathrm{z}}$ & $\mathrm{SD}^{\mathrm{y}}$ & $\mathrm{LN}^{\mathrm{x}}$ & $\mathrm{LC}^{\mathrm{w}}$ & $\mathrm{LA}^{\mathrm{v}}$ & $\mathrm{LFW}^{\mathrm{u}}$ & $\mathrm{SFW}^{\mathrm{t}}$ & $\mathrm{RFW}^{\mathrm{s}}$ & $\mathrm{TFW}^{\mathrm{r}}$ & $\mathrm{LDW}^{\mathrm{q}}$ & $\mathrm{SDW}^{\mathrm{p}}$ & $\mathrm{RDW}^{\mathrm{o}}$ & $\mathrm{TDW}^{\mathrm{n}}$ \\
\hline $\mathrm{TRR}^{\mathrm{m}}$ & $0.29^{*}$ & -0.11 & $0.27^{*}$ & 0.12 & $0.41^{*}$ & $0.32^{*}$ & $0.32^{*}$ & -0.02 & $0.31^{*}$ & $0.29^{*}$ & 0.18 & -0.05 & $0.21^{*}$ \\
$\mathrm{CP}^{\mathrm{l}}$ & $0.82^{*}$ & $0.72^{*}$ & $0.89^{*}$ & $0.65^{*}$ & $0.78^{*}$ & $0.58^{*}$ & $0.87^{*}$ & $0.94^{*}$ & $0.76^{*}$ & $0.94^{*}$ & $0.93^{*}$ & $0.95^{*}$ & $0.95^{*}$ \\
$\mathrm{DQI}^{\mathrm{k}}$ & $0.84^{*}$ & $0.82^{*}$ & $0.87^{*}$ & $0.69^{*}$ & $0.77^{*}$ & $0.55^{*}$ & $0.86^{*}$ & $0.98^{*}$ & $0.74^{*}$ & $0.92^{*}$ & $0.94^{*}$ & $0.99^{*}$ & $0.95^{*}$ \\
\hline
\end{tabular}

* Pearson correlation significant at the $5 \%$ probability level; ${ }^{\mathrm{z}}$ Plant height; ${ }^{\mathrm{y}}$ Stem diameter; ${ }^{\mathrm{x}}$ Leaf number; ${ }^{\text {w} L e a f ~ c o l o r ; ~}{ }^{\mathrm{V}} \mathrm{Leaf}$ area; ${ }^{\mathrm{u} L e a f}$ fresh weight; ' Stem fresh weight; ${ }^{\mathrm{s}}$ Root fresh weight; ${ }^{\mathrm{r}}$ Total fresh weight; ${ }^{\mathrm{q}}$ Leaf dry weight; ${ }^{\mathrm{p}}$ Stem dry weight; ${ }^{\circ}$ Root dry weight; ${ }^{\mathrm{n}}$ Total dry weight; ${ }^{\mathrm{m}}$ Top to root ratio; ${ }^{\mathrm{l} C o m p a c t n e s s} ;{ }^{\mathrm{k}}$ Dickson quality index.

$2.0 \mathrm{~S}$ 농도에서는 차이가 있었다.

$\mathrm{DQI}$ 의 경우에도 묘령이 경과할수록 높아졌으며, 충실 도와 비슷한 양상을 보였다(Table 6). 접목활착 후 30 일 에는 시비수준 $2.0 \mathrm{~S}, 1.0 \mathrm{~S}, 0.5 \mathrm{~S}$ 순으로 높았으며, 접목 활착 후 40 일에는 $0.5 \mathrm{~S}$ 에서만 낮았다. 품종별로는 접목 활착 후 30 일에는 '대프니스'가 높았고, 40 일에는 '대프 니스'와 '도태랑다이아'가 '마스카라' 보다 높은 것으로 나타나 전반적으로 '대프니스' 품종이 높은 경향이었다.

이러한 충실도와 $\mathrm{DQI}$ 의 변화에서 접목활착 후 10 일에
서 20 일까지는 시비수준 효과가 크게 나타나지 않다가 그 이 후부터 시비수준 효과가 커진 것으로 판단되었다. 또한, 충실도와 $\mathrm{DQD}$ 가 비슷한 양상을 보였기 때문에 고도 로 유의한 회귀직선 $\left(\mathrm{Y}=-0.0256+0.0029 * \mathrm{X}\right.$, Adj $\mathrm{R}^{2}=0.9480$, $\mathrm{p}<0.0001$ )을 구할 수 있었다(Fig. 2).

Table 7은 육묘기에 시비 처리를 받은 원통형 종이포 트 토마토 접목묘의 정식 후 2주간에 야간온도 처리에 따른 상대생장률(RGR)을 나타낸 것이다. 묘령이 높아질 수록 RGR은 감소하는 경향을 보였다. 접목 활착후 10 일 
$\mathrm{DQI}$ 와 단기 상대생장률 분석을 이용한 원통형 종이포트 토마토 접목묘의 우량묘 기준 설정

Table 4. Top and root ratio (TRR) of grafted tomato seedlings investigated at 10, 20, 30, and 40 DAGT as affected by the strength of nutrient solution for fertigation.

\begin{tabular}{|c|c|c|c|c|c|}
\hline \multirow{2}{*}{$\begin{array}{l}\text { Strength of Fertigation } \\
\text { (A) }\end{array}$} & \multirow{2}{*}{$\begin{array}{l}\text { Cultivars } \\
\text { (B) }\end{array}$} & \multicolumn{4}{|c|}{ "TRR } \\
\hline & & 10 DAGT & 20 DAGT & 30 DAGT & 40 DAGT \\
\hline \multirow[t]{3}{*}{$0.5 \mathrm{~S}^{\mathrm{Z}}$} & $\mathrm{DF}^{\mathrm{y}}$ & 5.65 & 5.17 & 6.36 & 4.90 \\
\hline & DD & 8.06 & 9.15 & 5.24 & $-x$ \\
\hline & MK & 5.54 & 5.88 & 5.34 & 6.43 \\
\hline \multirow[t]{3}{*}{$1.0 \mathrm{~S}$} & DF & 6.16 & 6.33 & 5.60 & 6.05 \\
\hline & DD & 8.66 & 8.25 & 7.86 & 6.75 \\
\hline & MK & 5.28 & 6.89 & 6.51 & - \\
\hline \multirow[t]{3}{*}{$2.0 \mathrm{~S}$} & DF & 7.25 & 7.62 & 6.76 & - \\
\hline & DD & 6.91 & 8.57 & 7.97 & 8.68 \\
\hline & MK & 7.11 & 8.77 & 7.61 & 9.28 \\
\hline \multicolumn{6}{|l|}{ F-test $^{\mathrm{w}}$} \\
\hline $\mathrm{A}$ & & ns & $* *$ & $* * *$ & $* * *$ \\
\hline B & & $* *$ & $* * *$ & ns & $*$ \\
\hline $\mathrm{A} \times \mathrm{B}$ & & ns & $*$ & $* * 1$ & ns \\
\hline
\end{tabular}

${ }^{2} \mathrm{~N}-\mathrm{P}-\mathrm{K}-\mathrm{Ca}-\mathrm{Mg}=8.0-2.4-2.4-4.8-1.6-1.6 \mathrm{me} \cdot \mathrm{L}^{-1}$

'DF; 'Dafnis', DD; 'DOTAERANG DIA', MK; 'Maescala'

${ }^{\mathrm{x}}$ Missing data

${ }^{\mathrm{w}} \mathrm{ns},{ }^{*}, * * * * *$; Nonsignificant or significant at $P \leq 0.05,0.01$, and 0.0001 , respectively.

Table 5. Compactness (CP) of tomato grafted seedlings investigated at 10, 20, 30, and 40 DAGT as affected by the strength of nutrient solution for fertigation.

\begin{tabular}{|c|c|c|c|c|c|}
\hline \multirow{2}{*}{$\begin{array}{l}\text { Strength of Fertigation } \\
\text { (A) }\end{array}$} & \multirow{2}{*}{$\begin{array}{l}\text { Cultivars } \\
\text { (B) }\end{array}$} & \multicolumn{4}{|c|}{ Compactness (mg/cm) } \\
\hline & & 10 DAGT & 20 DAGT & 30 DAGT & 40 DAGT \\
\hline \multirow[t]{3}{*}{$0.5 \mathrm{~S}^{\mathrm{z}}$} & $\mathrm{DF}^{\mathrm{y}}$ & 18.3 & 29.0 & 51.4 & 53.6 \\
\hline & DD & 19.9 & 36.2 & 36.9 & $--^{x}$ \\
\hline & MK & 18.4 & 31.2 & 46.6 & 56.0 \\
\hline \multirow[t]{3}{*}{$1.0 \mathrm{~S}$} & DF & 18.0 & 32.4 & 50.4 & 65.4 \\
\hline & DD & 18.9 & 34.6 & 49.0 & 62.9 \\
\hline & MK & 18.0 & 33.2 & 44.6 & - \\
\hline \multirow[t]{3}{*}{$2.0 \mathrm{~S}$} & DF & 18.5 & 33.8 & 54.5 & - \\
\hline & $\mathrm{DD}$ & 20.0 & 38.1 & 56.1 & 75.2 \\
\hline & MK & 20.3 & 32.6 & 45.2 & 58.9 \\
\hline \multicolumn{6}{|l|}{ F-test ${ }^{\mathrm{w}}$} \\
\hline $\mathrm{A}$ & & $\mathrm{ns}$ & ns & $* *$ & ns \\
\hline $\mathrm{B}$ & & ns & ns & $* *$ & ns \\
\hline $\mathrm{A} \times \mathrm{B}$ & & ns & ns & $* *$ & $\mathrm{~ns}$ \\
\hline
\end{tabular}

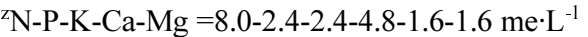

'DF; 'dafnis', DD; 'DOTAERANG DIA', MK; 'Maescala'

${ }^{\mathrm{x}}$ Missing data

wns, ${ }^{*}, * * * * *$; Nonsignificant or significant at $P \leq 0.05,0.01$, and 0.0001 , respectively.

의 RGR 조사 자료가 유실이 되어 나타내지 못했다. 육 묘기 시비수준에 따른 접목 활착 후 20 일묘의 RGR은
$1.0 \mathrm{~S}$ 와 $0.5 \mathrm{~S}$ 처리에서 $2.0 \mathrm{~S}$ 처리보다 높았다. 이 시기에 야간온도별 비교에서는 $25^{\circ} \mathrm{C}$ 처리가 $15^{\circ} \mathrm{C}$ 와 $10^{\circ} \mathrm{C}$ 처리 
서태철 - 안세웅 - 장현우 - 남춘우 - 전희 - 김영철 - 강태경 - 이상희

Table 6. DQI of tomato grafted seedlings investigated at 10, 20, 30, and 40 DAGT as affected by the strength of nutrient solution for fertigation.

\begin{tabular}{|c|c|c|c|c|c|}
\hline \multirow{2}{*}{$\begin{array}{l}\text { Strength of Fertigation } \\
\text { (A) }\end{array}$} & \multirow{2}{*}{$\begin{array}{l}\text { Cultivars } \\
\text { (B) }\end{array}$} & \multicolumn{4}{|c|}{ 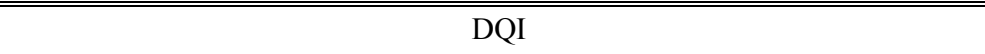 } \\
\hline & & 10 DAGT & 20 DAGT & 30 DAGT & 40 DAGT \\
\hline \multirow[t]{3}{*}{$0.5 \mathrm{~S}^{\mathrm{z}}$} & $\mathrm{DF}^{\mathrm{y}}$ & 0.033 & 0.064 & 0.108 & 0.149 \\
\hline & DD & 0.028 & 0.057 & 0.082 & $-{ }^{x}$ \\
\hline & MK & 0.029 & 0.058 & 0.099 & 0.129 \\
\hline \multirow[t]{3}{*}{$1.0 \mathrm{~S}$} & DF & 0.033 & 0.070 & 0.131 & 0.191 \\
\hline & $\mathrm{DD}$ & 0.027 & 0.062 & 0.108 & 0.160 \\
\hline & MK & 0.030 & 0.065 & 0.100 & - \\
\hline \multirow[t]{3}{*}{$2.0 \mathrm{~S}$} & DF & 0.032 & 0.073 & 0.146 & - \\
\hline & DD & 0.034 & 0.075 & 0.131 & 0.177 \\
\hline & MK & 0.032 & 0.061 & 0.109 & 0.143 \\
\hline \multicolumn{6}{|l|}{ F-test ${ }^{w}$} \\
\hline A & & ns & ns & $* * *$ & * \\
\hline B & & ns & $\mathrm{ns}$ & $* * *$ & $*$ \\
\hline$A \times B$ & & ns & ns & $*$ & ns \\
\hline
\end{tabular}

${ }^{\mathrm{z}} \mathrm{N}-\mathrm{P}-\mathrm{K}-\mathrm{Ca}-\mathrm{Mg}=8.0-2.4-2.4-4.8-1.6-1.6 \mathrm{me} \cdot \mathrm{L}^{-1}$

'DF; 'dafnis', DD; 'DOTAERANG DIA', MK; 'Maescala'

${ }^{\mathrm{x}}$ Missing data

wns, ${ }^{*}, * * * * * ;$ Nonsignificant or significant at $P \leq 0.05,0.01$, and 0.0001 , respectively.

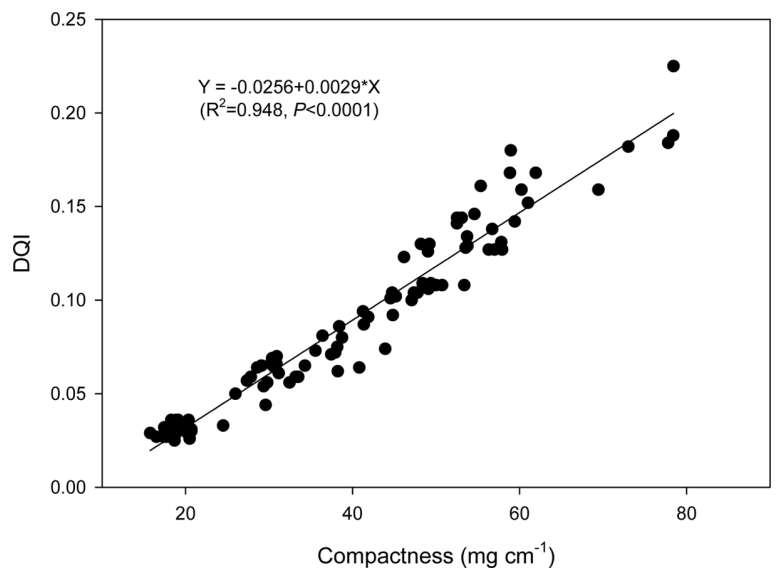

Fig. 2. Linear regression of compactness and DQI in grafed tomato seedling grown for from 10 to 40 DAGT as affected by the strength of nutrient solution for fertigation.

보다 RGR이 높았다. 품종별 비교에서는 ‘대프니스'와 '마 스카라'가 ‘도태랑다이아'보다 높았다. 접목 활착 후 30 일 묘의 경우에는 시비수준 간 비교에서는 $2.0 \mathrm{~S}$ 와 $1.0 \mathrm{~S}$ 가 $0.5 \mathrm{~S}$ 처리에 비해 높았다. 그러나 야간온도에 따른 차이는 없었다. 품종별 비교에서는 '마스카라'가 '대프니 스'와 '도태랑다이아' 보다 높았다. 접목 활착 후 40 일 묘는 모든 처리별 효과가 없었다. 상대생장률은 작물에

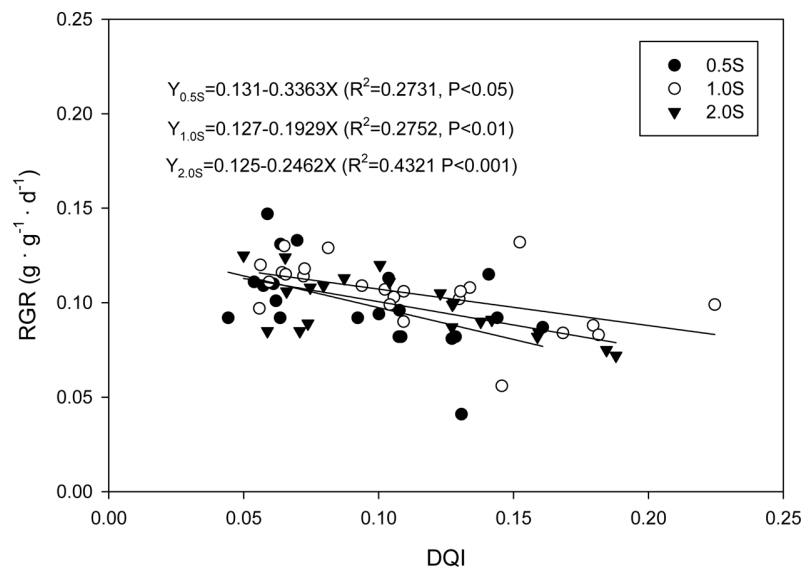

Fig. 3. The linear regression of DQI and RGR of grafted tomato seedlings grown in 40 cell cylindrical paper pot tray for from 20 to 40 DAGT as affected by the strength of nutrient solution for fertigation

따라 생육시기별 양상은 다르지만 일반적으로 생육기간 이 경과할수록 낮아지는 경향을 보이는 것으로 알려져 있으며(Hoffman and Pooter, 2002; Rees et al., 2010), 본 실험 결과도 같은 경향을 보였다. 토마토는 온대성 작물로서 전 생육기간 생육적온은 $18.3 \sim 32.2^{\circ} \mathrm{C}$ 범위이고, 최고온도는 $30 \sim 35^{\circ} \mathrm{C}$ 이상 올라가지 않아야 하며, 토마 토 육묘기에는 주간 $27^{\circ} \mathrm{C}$, 야간 $18^{\circ} \mathrm{C}$ 범위라고 한다 
$\mathrm{DQI}$ 와 단기 상대생장률 분석을 이용한 원통형 종이포트 토마토 접목묘의 우량묘 기준 설정

Table 7. Effect of the strength of nutrient solution fertigated during the nursery period and the night temperature after planting on the relative growth rate (RGR) of grafted tomato for two weeks grown in $\varnothing 15 \mathrm{~cm}$ plastic pot filled with commercial bed soil at 10,20,30, and 40 DAGT, respectively.

\begin{tabular}{|c|c|c|c|c|c|c|}
\hline $\begin{array}{l}\text { Strength of } \\
\text { fertigation } \\
\text { (A) }\end{array}$ & $\begin{array}{l}\text { Night temperature } \\
\text { (B) }\end{array}$ & $\begin{array}{l}\text { Cultivars }^{y} \\
\text { (C) }\end{array}$ & 10 DAGT & 20 DAGT & 30 DAGT & 40 DAGT \\
\hline \multirow[t]{9}{*}{$0.5 \mathrm{~S}^{\mathrm{z}}$} & $10^{\circ} \mathrm{C}$ & DF & $-{ }^{x}$ & 0.131 & 0.082 & 0.115 \\
\hline & & DD & - & 0.092 & - & - \\
\hline & & MK & - & 0.111 & 0.113 & 0.041 \\
\hline & $15^{\circ} \mathrm{C}$ & DF & - & 0.109 & 0.096 & 0.092 \\
\hline & & DD & - & 0.092 & - & - \\
\hline & & MK & - & 0.110 & 0.094 & 0.081 \\
\hline & $25^{\circ} \mathrm{C}$ & DF & - & 0.133 & 0.082 & 0.087 \\
\hline & & $\mathrm{DD}$ & - & 0.101 & - & - \\
\hline & & MK & - & 0.147 & 0.092 & 0.082 \\
\hline \multirow[t]{9}{*}{$1.0 \mathrm{~S}$} & $10^{\circ} \mathrm{C}$ & $\mathrm{DF}$ & - & 0.116 & 0.108 & 0.088 \\
\hline & & $\mathrm{DD}$ & - & 0.097 & 0.090 & 0.083 \\
\hline & & MK & - & 0.120 & 0.109 & - \\
\hline & $15^{\circ} \mathrm{C}$ & DF & - & 0.115 & 0.102 & 0.084 \\
\hline & & DD & - & 0.111 & 0.106 & 0.132 \\
\hline & & MK & - & 0.118 & 0.099 & - \\
\hline & $25^{\circ} \mathrm{C}$ & DF & - & 0.129 & 0.106 & 0.099 \\
\hline & & DD & - & 0.114 & 0.103 & 0.056 \\
\hline & & MK & - & 0.130 & 0.107 & - \\
\hline \multirow[t]{9}{*}{$2.0 \mathrm{~S}$} & $10^{\circ} \mathrm{C}$ & DF & - & 0.106 & - & - \\
\hline & & $\mathrm{DD}$ & - & 0.085 & 0.100 & 0.075 \\
\hline & & MK & - & 0.089 & 0.105 & 0.084 \\
\hline & $15^{\circ} \mathrm{C}$ & DF & - & 0.113 & - & - \\
\hline & & DD & - & 0.109 & 0.090 & 0.072 \\
\hline & & MK & - & 0.085 & 0.111 & 0.087 \\
\hline & $25^{\circ} \mathrm{C}$ & DF & - & 0.124 & - & - \\
\hline & & DD & - & 0.108 & 0.099 & 0.082 \\
\hline & & MK & - & 0.125 & 0.120 & 0.091 \\
\hline \multicolumn{7}{|l|}{ F-test ${ }^{\mathrm{w}}$} \\
\hline & A & & - & ns & $* *$ & ns \\
\hline & B & & - & $* * *$ & ns & ns \\
\hline & $\mathrm{C}$ & & - & $* * *$ & $* *$ & ns \\
\hline & $\mathrm{A} \times \mathrm{B}$ & & - & ns & ns & ns \\
\hline & $\mathrm{A} \times \mathrm{C}$ & & - & $*$ & ns & $\mathrm{ns}$ \\
\hline & $\mathrm{B} \times \mathrm{C}$ & & - & ns & ns & ns \\
\hline & $\mathrm{A} \times \mathrm{B} \times \mathrm{C}$ & & - & ns & ns & ns \\
\hline
\end{tabular}

${ }^{\mathrm{z}} \mathrm{N}-\mathrm{P}-\mathrm{K}-\mathrm{Ca}-\mathrm{Mg}=8.0-2.4-2.4-4.8-1.6-1.6 \mathrm{me} \cdot \mathrm{L}^{-1}$

yDF; 'dafnis', DD; 'DOTAERANG DIA', MK; 'Maescala'

${ }^{\mathrm{x}}$ Missing data

wns, ${ }^{* * *}, * * ;$ Nonsignificant or significant at $P \leq 0.05,0.01$, and 0.0001 , repspectively. 
(Shamshiri 등, 2018). 본 실험은 정식 후 초기 2주간의 야간온도 처리효과를 본 것으로 유리온실 조건에서 야간 온도 처리가 의도한 대로 이루어지지는 않았지만(Table 1) 접목활착 후 20 일묘의 처리 기간 까지는 야간온도가 높은 $25^{\circ} \mathrm{C}$ 처리가 다른 두 처리에 비해서 $\mathrm{RGR}$ 이 높았 던 것으로 판단된다.

중요한 것은 묘소질과 정식 후 포장에서의 최고의 능 력을 발휘할 수 있는 최적의 묘소질을 찾는 것이고 그 묘소질을 평가할 수 있는 기준을 설정하는 것이라고 생 각된다. 본 실험에서는 묘소질 지표 가운데 생육인자와 높은 정의 상관관계를 보인 $\mathrm{DQI}$ 와 $\mathrm{RGR}$ 과의 선형회귀 분석을 시비수준별로 실시한 결과, 각 회귀식의 설명력 은 낮았지만 유의하게 모든 농도에서 $\mathrm{DQI}$ 가 높아짐에 따라 $\mathrm{RGR}$ 이 감소하였으며, 감소 기울기는 $1.0 \mathrm{~S}, 2.0 \mathrm{~S}$, $0.5 \mathrm{~S}$ 순으로 낮았다(Fig. 3). 일반적으로 식물생장모델에 서 선형함수모델에서는 절대생장률(AGR)이 일정하며, 지수함수모델에서는 RGR이 일정하다(Paine et al., 2012). 본 실험에서는 RGR이 시비수준에 따른 차이는 있었지만 전체적으로 감소하는 경향을 보였기에 정식 후 정식 후 초기 2 주간의 토마토의 생장은 지수함수모델은 아닌 것으로 판단되었다.

결과적으로 육묘기 시비수준 처리에 따른 접목 토마토 묘의 $\mathrm{DQI}$ 와 정식 2주 후의 단기 상대생장률의 분석을 통하여 $\mathrm{DQD}$ 가 높을수록 $\mathrm{RGR}$ 의 감소 정도가 낮았고, 특 히 표준 시비수준 $1.0 \mathrm{~S}$ 에서 $\mathrm{RGR}$ 이 높게 유지되었기 때 문에 이때의 $\mathrm{DQI}$ 값과 육묘일수 등을 고려하여 우량묘 의 묘소질 범위를 설정할 수 있을 것으로 판단된다. 본 실험은 육묘기의 광과 온도조건 등 환경조건이 양호하고, 피트모스 주원료의 종이포트용 전용상토, 그리고 종이포 트 부피 $53 \mathrm{~mL}$ 의 조건에서 수행되었기에 양질의 토마토 접목묘가 포함되었을 것으로 판단된다. 그러나 이를 실 용적으로 현장에서 활용하기 위해서는 다양한 조건에서 생산된 묘의 $\mathrm{DQI}$ 와 정식 후의 성능평가에 대한 정보가 더 축적되어야 하고, DQI를 빠르고 정확하게 분석할 수 있는 영상분석 기술 적용에 대한 연구가 수반되어야 할 것으로 생각된다. 또한, 정식 후 성능평가 수단으로 $\mathrm{RGR}$ 보다 좀 더 좋은 방법, 그리고 개화와 관련된 특성 이 묘소질과도 밀접한 관련이 있으므로 이에 대한 연구 와 리뷰가 더 이루어져야 할 것으로 판단된다.

\section{적 요}

3종의 일반토마토 '대프니스', '도태랑다이아', '마스카라' 를 대목 ' $\mathrm{B}$ 블로킹'에 접목하고 접목 활착 후 10 일부터 10 일 간격으로 40 일 까지 육묘용 표준양액 $(\mathrm{S})$ 의 $0.5 \mathrm{~S}, 1,0 \mathrm{~S}$, $2,0 \mathrm{~S}$ 로 시비수준 처리를 하였다. 각 시기별로 묘의 생육
인자들을 조사하였고, 묘소질 지표인 $\mathrm{TR}$ 율, 충실도, $\mathrm{DQI}$ 를 계산하였다. 그리고 생육인자들과 묘소질 지표와의 상 관관계를 분석하였고, 묘령별로 야간온도를 $10,15,25^{\circ} \mathrm{C}$ 를 목표로 3수준으로 처리하여 상대생장률(RGR)을 분석 하였다. 그 결과, 토마토 접목묘의 양적인 생육인자들은 모두 시비농도가 높을수록 증가하였고, 다양한 크기 범위 의 묘를 생산할 수 있었다. 그리고 묘의 바이오메스 관련 생육인자가 충실도와 $\mathrm{DQI}$ 에 높은 정의상관이 있음을 알 수 있었으며, 충실도와 DQI의 고도로 유의한 1 차 선형회 귀식( $\left(\mathrm{Y}=-0.0256+0.0029 * \mathrm{X}, \operatorname{Adj} \mathrm{R}^{2}=0.9480, \mathrm{p}<0.0001\right)$ 이 도출되었다. 정식 후 2 주간의 $\mathrm{RGR}$ 은 묘령이 높아질수 록 감소하는 경향을 보였고, 육묘기 시비수준에 따라서 는 접목활착 후 30 일묘와 40 일묘에서 표준 시비수준 $1.0 \mathrm{~S}$ 에서 RGR이 높았다. 시비수준별 육묘기 $\mathrm{DQI}$ 와 정 식후 초기 RGR과 유의한 선형회귀식을 도출하였으며, 표준 시비수준 $1.0 \mathrm{~S}$ 에서 $\mathrm{DQD}$ 가 높아짐에 따라 $\mathrm{RGR}$ 이 높게 유지되었다. 이러한 결과는 $\mathrm{DQ}$ 가 원통형 종이포 트 토마토 접목묘의 묘소질의 지표로 이용될 수 있고, $\mathrm{DQI}$ 와 정식 후 초기 상대생장률과의 관계분석을 통하여 우량묘의 기준 설정에 활용될 수 있을 것이다.

추가 주제어 : 육묘, 설정, 기준, 성능, 절대생장률

\section{사 사}

본 논문은 농촌진흥청 연구사업(세부과제번호: PJ012 827012018)의 지원에 의해 이루어진 것임.

\section{Literature cited}

Ägren, G.I. and O. Franklin. 2003. Root: shoot ratios, optimization and nitrogen productivity. Annals of Botany 92: 795800.

Ahn, C.K., Y.W. Choi, B.G. Son, J.S. Kang. 2003. Productionof high quality tomato seedlings by $\mathrm{CO}_{2}$ and temperature control in glass house. J. Kor. Soc. Hort. Sci. 44(2): 182-186.

Balliu, A., A. Bani, and Sulçe. 2007. Nitrogen effects on the relative growth rate and its components of pepper (Capsicum annuum) and eggplant (Solanum melongena) seedlings. Acta Hortic. 747: 257-262.

Dickson, A., A.L. Leaf, and J.F. Hostner. 1960. Quality appraisal of white spruce and white pine seedling stock in nurseries. The Forestry Chronicle 36(1): 10-13 http:// doi.org/10.5558/tfc36010-1.

ELLEPOT. 2017. Why ellepot? http://www.ellepot.com/whyellepot.

Hoffman, W.A. and H. Poorter. 2002. Avoiding bias in calculations of relative growth rate. Annals of Botany 80: 37-42 
http://doi.org/10.1093/aob/mcf140.

Kim, H.C., Y.H. Cho, Y.G. Ku, and J.H. Bae. 2015. Seedling qualities of hot pepper according to seedling growth periods and growth and yield after planting. Korean J. Hort. Sci. Technol. 33(6): 839-844 http://doi.org/10.7235/hort.2015.15083.

Kim, S.E., M.H. Lee, B.J. Ahn, and Y.S. Kim. 2013. Effect of spacing and plug cell size on seedling quality and yield and qualities of tomatoes. Protected Horticulture and Plant Factory 22(3): 251-261 http://doi.org/10.12791/KSBEC.2013.22.3.256.

Kubo, S., N. Shimada, and N. Okamoto. 1991. The effects of nutrient levels in nursery soils on plant quality of cucumber, tomato, eggplant and melon seedlings. J. Japan. Soc. Hort. Sci. 60(3): 555-566 https://doi.org/10.2503/jjshs.60.555.

Lee, J.S., H.I. Lee, and Y.H. Kim. 2012. Seedling quality and early yield after transplanting of paprika nursed under lightemitting diodes, fluorescent lamps and natural light. Journal of Bio-Environmental Control 21(3): 220-227.

Lee, J.W., K.Y. Kim, and Y.M. Yu. 2001. Effect of Nutrient solution strength, seedling age, and container size on seedling quality and yield of 'Spirit' colored bell pepper (Capsicum annuum L.). J. Kor. Soc. Hort. Sci. 42(3): 300-304.

Leskovar, D.I. and P.J. Stoffela. 1995. Vegetable seedling root systems: morphology, development, and importance. HortScience 30(6): 1153-1159.

Mattson, A. 1996. Predicting field performance using seedling quality. New Forests 13: 223-248 http://doi.org/ 10.1023/A:1006590409595.

Mota, C.S., F.G. Silva, P. Dornelles, A.C. Costa, E.L.S. Araujo, and G.C. Mendes. 2016. Use of physiological parameters to assess seedlings quality of Eugenia dysenterica DC. grown in different substrates. Australian Journal of Crop Science 10(6): 842-851 http://doi.org/10.21475/ ajcs.2016.10.06.p7501.

Paine, C.E.T., T.R. Marthews, D.R. Vogt, D. Purves, M. Rees,
A. Hector, and L.A. Turnbull. 2012. How to fit nonlinear plant growth models and calculate growth rates: an update for ecologists. Methods in Ecology and Evolution 2012(3): 245-256 http://doi.org/10.1111/j.2041-210X.2011.00155.x

Pak, H.Y., K.C. Son, E.G. Gu, K.B. Lim, and B.H. Kim. 1996. Effect of different day and night temperature regimes on the growth of hot pepper plug seedlings. J. Koc. Hort. Sci. 37(5): 617-621.

RDA. 2008. Standard farming manual-84: Vegetable nursery technology. 1st ed. RDA. Korea. p. 40-41.

Rees, M., C.P. Osborne, F.I. Woodward, S.P. Hulme, L.A. Turnbull, and S.H. Taylor. 2010. Partitioning the components of relative growth rate: How important is plant size variation?. The American Naturalist 176(6): E152-E161.

Seo, J.U., J.M. Hwang, and S.M. Oh. 2006. Effects of night temperature treatment of raising seedlings before transplanting on growth and development of pepper. Journal of BioEnvrionment Control 15(2): 149-155.

Seo, T.C., S.W. An, S.M. Kim, C.W. Nam, H. Chun. et al. 2017. Effect of seedling difference in cylindrical paper pot trays on initial root growth and yield of pepper. Protected Horticulture and Plant Factory 26(4): 368-377 http://doi.org/ 10.12791/KSBEC.2017.26.4.368.

Shamshiri, R.R., J.W. Jones, K.R. Thorp, D. Ahmaa, H.C. Man, and S. Taheri. 2018. Review of optimum temperature, humidity, and vapour pressure deficit for microclimate evaluation and control in greenhouse cultivation of tomato: a review. International Agrophysics 32: 287-302 http:// doi.org/10.1515/intag-2017-0005.

Shipley, B. 2006. Net assimilation rate, specific leaf area and leaf mass ratio: which is most closely correlated with relative growth rate? A meta-analysis. Functional Ecology 20: 565-574 http://doi.org/10.1111/j.1365-2435.2006.01135.x. 